\title{
Identification of Cow-related Health Disorders Affecting the Culling in Torbat-e Jam Dairy Farms
}

\author{
Elias Ibrahimi Khorram Abadi \& Mohsen Kazemi \\ Faculty of Agriculture and Animal Science, University of Torbat-e Jam, Torbat-e Jam, Iran.
}

Received: November 6, 2017

doi:10.5296/jas.v6i1.12105
Accepted: November 27, 2017

URL: https://doi.org/10.5296/jas.v6i1.12105

\begin{abstract}
An experiment was conducted to assess characterization of cow-related health disorders affecting the culling in Torbat-e Jam dairy farms. In total, the data of 5874 lactating cows have been used in this study (1997 to 2017). The logistic regression was applied to investigate the associations between the response variable, the risk of culling, and predictor variables including the parity, calving ease, birth type, calving season, and age at the first calving. The risk of culling increased with parity and twinning $(\mathrm{P}<0.001)$. The odds ratio (OR) of a cow leaving the herd were 1, 1.17, 1.35, 2.06, 2.95 and 3.55 for parities 1 to 6 , respectively, 1 and 1.14 for twinning. The OR increased with increasing in calving difficulty score $(\mathrm{P}<0.001)$. The $\mathrm{OR}$ were 1, 1.21, 1.26 and 2.30 for calving difficulty score 1 to 4 , respectively. Calving in hot season increased the risk of culling $(\mathrm{P}<0.001)$. The OR were 1 , $1.59,1.46$ and 1.06 for spring, summer, fall and winter respectively. Cows that calved first at about 24 months of age had a lower risk of culling ( $\mathrm{P}<0.001)$. These findings help farmers reduce their involuntary culling rates in dairy herds by improving the management of dairy cows in Torbat-e Jam.
\end{abstract}

Keywords: Culling, Holstein dairy herds, Torbat-e-Jam, Iran

\section{Introduction.}

The health and proper conditions for breeding livestock are very important issues due to focus of consumers on the livestock products quality and safety, in recent years. It is always said as a principle that optimum conditions guarantee the proper growth of the livestock. Exposure of the animals to various diseases and bred in inappropriate conditions may cause decrease quality and safety of domestic animal productions (HAS, 2013).

Lack of attention to the health status of the cow increases the risk of culling from the herd. The departure of the cow from the herd for some reason such as sale, slaughter, death, aging and infertility, is known as culling (Fetrow et al., 2006). Culling rate has been rising recently due to sub-optimal health and inadequate welfare and management practices (Thomsen et al., 
2006 and McConnel et al., 2008). Culling is complicated issue and influenced by many voluntary and involuntary factors such as management style, herd and cow-related characteristics (Booth et al., 2004; Didarkhah et al., 2013; Bahrampour et al., 2016). However the information about the connection cow-related characteristics and culling is little.

Further knowledge about herd health status and cow-related characteristics may lead to development of programs for better animal welfare, reducing of involuntary culling and increase quality and safety production in Iranian dairy farms. So this experiment was carried out to identify characterization of factors affecting animal health and culling rate in Torbat-e Jam dairy farms, one of the biggest dairy producing regions in Iran, Khorasan Razavi Province.

\section{Materials and Methods.}

\subsection{Data}

The experiment was conducted in Khorasan Razavi Province, Torbat-e Jam area, as one of the most important centers for producing dairy product in Northeast of Iran. A commercial dairy herd milking Holstein cattle were used in this study. Herd sizes were 5874 lactating cows for 20 years period. This herd were used because of the completeness records farmer compliance and full time on-staff veterinarian. Any missing information about parity number, calving and culling date were not included in the study. Also the data related to cow with calving intervals more than $600 \mathrm{~d}$ and lower $300 \mathrm{~d}$ and cow with first calving before age 20 or after 40 months and with parity more than 12 were removed from the study.

\subsection{Outcome and Predictor Variables}

The outcome variable was the risk of culling regardless of reason. The predictor cow-related characteristics variables included the calving season: spring (21 March to 21 June), summer (22 June to 22 September), fall (23 September to 21 December) and winter (22 December to $20 \mathrm{March}$ ), birth type: single or twins, calving difficulty scores: $1=$ normal (not assisted), $2=$ moderate assistance (farmer), $3=$ moderate assistance (veterinarian culled as precaution), $4=$ very difficult (extraction by farm staff and veterinary assistance), and parity: $1,2,3,4,5$ and $\geq 6$.

\subsection{Statistical Analysis}

The logistic regression was used to analyse the associations between predictors and response variable. The effect of variables of interest on the odds ratio $(\mathrm{OR}=\mathrm{P} / 1-\mathrm{P})$ and risks of culling was estimated by using the logit-link in GLIMMIX procedure (SAS, 2008). The logistic regression model used for analysis was:

$$
\mathrm{Y}_{\mathrm{i}}=\beta_{0}+\beta_{1} \mathrm{X}_{\mathrm{i} 1}++\beta_{2} \mathrm{X}_{\mathrm{i} 2}+\ldots+\beta_{\mathrm{p}-1} \mathrm{X}_{(\mathrm{p}-1) \mathrm{i}}
$$

Where:

$\mathrm{Y}_{\mathrm{i}}=$ response variable

$X_{1 i}, X_{2 i}, \ldots, X_{(p-1) i}=$ indicate the independent variables 


\section{Macrothink}

$\beta_{0}, \beta_{1}, \beta_{2}, \ldots, \beta_{p-1}=$ indicate the regression parameters

\section{Result and Discussion.}

\subsection{Descriptive Statics}

Descriptive statics and distribution of studied variables in herd through the years are shown in table 1. During the 20 years, the highest percentage of calving cow was observed in the parity 1 and 6 or more. Also the highest percentage of culling rate was reported in parity 1 and 2 . The percentage of twins was much lower than singleton. However the number of culled singleton calf was much higher. In 20 past years, summer and fall have highest proportion of calving and spring and summer have highest proportion of culling. The percentage of culling course of 20 years is shown in Figure 1.

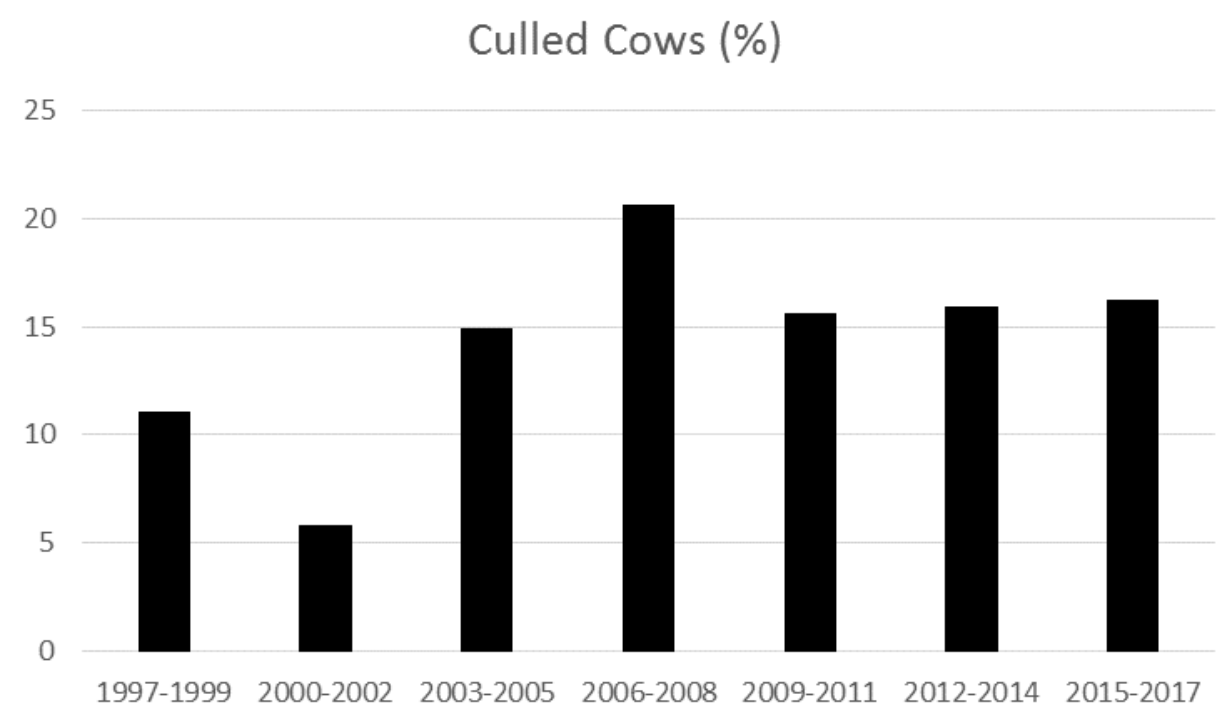

Figure 1. Percentage of culled Holstein cows through the years in Torbat-e Jam.

\subsection{Parity}

As shown in table 2, the rate of culling form the herd increased with parity $(\mathrm{P}<.001)$. The odds ratio of culling for cows removed from the herd with parity 1 to 6 or more, were 1.00, $1.17,1.25,2.06,2.95$ and 3.55 respectively (Table 2). These results are similar to the findings of Bahrampour et al. (2016) who observed an increase in risk of culling with odd ratio 1.00, $1.32,1.55$. 1.62, 1.67 and 1.88 when parity increased from 1 to 6 or more. De veries et al. (2010) obtained similar results. They observed in parity 1 to 6 or more, the risk of cows leaving the herd increased with score $1.00,1.51,2.14,2.68,3.11$ and 3.46, respectively. Pinedo et al. (2010) reported an increase in mortality in dairy cattle in United State and Denmark in parity 5 or more compared parity 1 to 4 . This finding is consistent with the result of current study. According to Mohammadi and Seddighi (2009) and Ansari-Lari et al. (2012), increase in cow age could increase mortality and culling rate in the dairy herds. The weakening of body immune system and subsequent incidence of certain disease in older ages 
could be the reason for increase mortality and culling rate in the dairy herds (Miller et al., 2008; Pinedo et al., 2010; Raboisson et al., 2011, Shahid et al., 2015; Bahrampour et al., 2016).

Table 1. Descriptive statics and distribution of studied variables in dairy herd through the years in Torbat-e Jam.

\begin{tabular}{|c|c|c|c|c|c|c|c|c|}
\hline Year (1997-2017) & & $97-99$ & $00-02$ & $03-05$ & 06-08 & 09-11 & $12-14$ & $15-17$ \\
\hline Number of cow (n) & & 654 & 870 & 859 & 865 & 865 & 860 & 865 \\
\hline Calving Cows (n) & & 79 & 43 & 71 & 53 & 67 & 58 & 37 \\
\hline Milk 305-d (Kg) & & 8235.1 & 8386.6 & 8455.9 & 8570.0 & 8611.4 & 8820.9 & 9744.7 \\
\hline Age at first calving & & 788 & 781 & 770 & 755 & 798 & 768 & 769 \\
\hline \multirow[t]{6}{*}{ Parity $(\%)$} & 1 & 22.78 & 16.27 & 25.35 & 28.30 & 28.35 & 12.06 & 10.81 \\
\hline & 2 & 20.25 & 09.30 & 11.26 & 07.54 & 16.41 & 08.62 & 02.70 \\
\hline & 3 & 11.39 & 20.93 & 12.67 & 13.20 & 16.41 & 22.41 & 02.70 \\
\hline & 4 & 10.12 & 16.27 & 11.26 & 15.09 & 11.94 & 24.13 & 18.91 \\
\hline & 5 & 11.39 & 11.62 & 14.08 & 07.54 & 10.44 & 08.62 & 21.62 \\
\hline & $\geq 6$ & 24.05 & 25.58 & 25.35 & 28.30 & 16.41 & 24.13 & 43.24 \\
\hline \multirow[t]{2}{*}{ Twins (\%) } & Singleton & 91.14 & 90.70 & 90.15 & 90.57 & 91.05 & 91.38 & 91.90 \\
\hline & Twin & 08.86 & 09.30 & 09.85 & 09.43 & 08.95 & 08.62 & 08.10 \\
\hline \multirow[t]{4}{*}{ Calving season (\%) } & Spring & 16.45 & 20.93 & 18.30 & 22.64 & 11.94 & 43.10 & 21.62 \\
\hline & Summer & 48.10 & 41.86 & 28.16 & 33.96 & 38.80 & 25.86 & 43.24 \\
\hline & Fall & 20.25 & 20.93 & 26.76 & 28.30 & 31.34 & 18.96 & 29.72 \\
\hline & Winter & 12.65 & 16.27 & 26.76 & 15.09 & 17.91 & 12.06 & 05.40 \\
\hline \multirow[t]{6}{*}{ Culling parity (\%) } & 1 & 19.50 & 20.20 & 21.40 & 28.50 & 32.07 & 33.20 & 35.50 \\
\hline & 2 & 23.80 & 24.10 & 24.40 & 24.30 & 24.30 & 24.50 & 25.50 \\
\hline & 3 & 20.10 & 19.60 & 19.70 & 18.50 & 17.60 & 17.40 & 18.80 \\
\hline & 4 & 13.40 & 13.10 & 13.30 & 12.10 & 11.30 & 11.10 & 12.20 \\
\hline & 5 & 09.10 & 08.40 & 08.54 & 07.10 & 06.60 & 06.40 & 06.60 \\
\hline & $\geq 6$ & 14.10 & 14.60 & 13.30 & 09.50 & 07.50 & 07.40 & 07.70 \\
\hline \multirow[t]{4}{*}{ Culling season (\%) } & Spring & 26.47 & 30.55 & 27.17 & 28.34 & 27.08 & 27.70 & 28.15 \\
\hline & Summer & 27.94 & 33.33 & 29.34 & 29.90 & 29.16 & 29.62 & 19.12 \\
\hline & Fall & 22.05 & 19.44 & 22.82 & 21.25 & 21.87 & 22.22 & 22.33 \\
\hline & Winter & 23.52 & 16.66 & 20.65 & 20.47 & 21.87 & 20.37 & 20.38 \\
\hline \multirow[t]{2}{*}{ Twins culling (\%) } & Singleton & 75.00 & 60.00 & 89.00 & 89.00 & 90.00 & 85.00 & 88.00 \\
\hline & Twin & 25.00 & 40.00 & 11.00 & 11.00 & 10.00 & 15.00 & 12.00 \\
\hline \multirow[t]{4}{*}{$\begin{array}{l}\text { Dystocia }{ }^{1} \text { culling } \\
(\%)\end{array}$} & 1 & 80.00 & 83.30 & 80.00 & 80.00 & 80.00 & 85.70 & 87.50 \\
\hline & 2 & 20.00 & 16.70 & 10.00 & 20.00 & 20.00 & 14.30 & 12.50 \\
\hline & 3 & 00.00 & 00.00 & 10.00 & 00.00 & 00.00 & 00.00 & 00.00 \\
\hline & 4 & 00.00 & 00.00 & 00.00 & 00.00 & 00.00 & 00.00 & 00.00 \\
\hline
\end{tabular}

${ }^{1} 1=$ normal (non-assisted); $2=$ moderate assistance (farmer); $3=$ moderate assistance (veterinarian culled); $4=$ very difficult. 
Table 2. Final logistic regression model, odds ratio, 95\% confidence interval and P-value for dairy herd risk factors in Torbat-e Jam.

\begin{tabular}{|c|c|c|c|c|}
\hline Predictor variable & & Odd ratio & $95 \%$ confidence interval & $\mathrm{P}$-value \\
\hline \multirow[t]{6}{*}{ Parity } & 1 & 1.00 & Ref & $<0.001$ \\
\hline & 2 & 1.17 & $0.46-1.06$ & \\
\hline & 3 & 1.25 & $0.86-1.80$ & \\
\hline & 4 & 2.06 & $1.46-2.89$ & \\
\hline & 5 & 2.95 & $2.13-4.10$ & \\
\hline & $\geq 6$ & 3.55 & $2.57-4.90$ & \\
\hline \multirow[t]{4}{*}{ Calving difficulty $^{1}$} & 1 & 1.00 & Ref & $<0.001$ \\
\hline & 2 & 1.21 & $1.17-1.23$ & \\
\hline & 3 & 1.26 & $1.21-1.30$ & \\
\hline & 4 & 2.30 & $2.28-2.34$ & \\
\hline \multirow[t]{2}{*}{ Birth } & singleton & 1.00 & Ref & $<0.001$ \\
\hline & twins & 1.14 & $1.11-1.15$ & \\
\hline \multirow[t]{4}{*}{ Calving season } & spring & 1.00 & Ref & $<0.001$ \\
\hline & summer & 1.59 & $1.23-2.06$ & \\
\hline & fall & 1.46 & $1.13-1.19$ & \\
\hline & winter & 1.06 & $0.81-1.39$ & \\
\hline \multirow[t]{4}{*}{ Age at first calving } & $\leq 728$ & 1.00 & Ref & $<0.001$ \\
\hline & $729-762$ & 1.56 & $1.47-1.62$ & \\
\hline & $763-815$ & 1.60 & $1.52-1.65$ & \\
\hline & $\geq 816$ & 1.94 & $1.72-2.11$ & \\
\hline
\end{tabular}

${ }^{1} 1=$ normal (non-assisted); $2=$ moderate assistance (farmer); $3=$ moderate assistance (veterinarian culled); $4=$ very difficult

\subsection{Calving Difficulty}

The risk of cows leaving the herd for calving difficulty are reported in Table 2. As the dystocia score increased there was an increase in the risk of cows leaving the herd, significantly $(\mathrm{P}<.001)$. The odds ratio of culling for calving difficulty recorded $1,1.21,1.26$, and 2.30 for dystocia score 1, 2, 3 and 4 respectively (Table 2). Recently, Bahrampour et al. (2016) observed that calving difficulty increased the risk of cows leaving the herd significantly. They reported that the hazard ratio of cow culled for calving difficulty were 1 , 0.89, 1.22, and 1.49 for dystocia score 1, 2, 3 and 4 respectively (Bahrampour et al., 2016). Reproductive disorders and calving difficulty is positively correlated to the mortality levels (McConnel et al., 2008). The previous research (Dematawewa and Berger 1998) demonstrated that dystocia score 4 and 5 , increase mortality level by more than $4 \%$ compared 
to dystocia score 1. Previous published studies have also reported increased about $20 \%$ in hazard ratio of cow culled for dystocia score 3 and 4 compared to dystocia score 1 and 2 (Bicalho et al., 2007). Shahid et al. (2015) revealed that mortality risk was markedly greater in dystocia score 3,4 and 5. Calving difficulty could have increased the risk of cows leaving the herd possibly due to increased reproductive disorders, decreased dry matter intake after calving, altered the hormonal status and subsequent decreased in milk and its components production (Barrier and Haskell, 2011; Atashi et al., 2012). Decreasing the risk of cows leaving the herd for calving difficulty score 4 to 1 could be attributable to on time presence of an assistant at parturition, provision of parturition confinement, better treatment and nutrition (Eaglen et al., 2011).

\subsection{Type of Birth}

The hazard ratio of cow culled for type of birth are shown in Table 2. The rate of culling form the herd increased with twining, significantly $(\mathrm{P}<.001)$. The odds ratio of culling for cows removed from the herd with type of birth singleton and twins, were 1.00 and 1.14 respectively (Table 2). The values from this experiment are similar to the findings of Bahrampour et al. (2016) who observed an increase in risk of culling with odd ratio 1.00 and 1.09 for type of birth singleton and twins, respectively. The observations from the previous experiment has shown that twining increased the risk of cows leaving the herd and mortality level by $42 \%$ compared to cow with singleton birth (Bicalho et al., 2007). Compared to cow with singleton birth, cows that calves twins, had higher the risk of culling and mortality level because of the experience of sever calving difficulty (De veries et al., 2010). Some previous studies demonstrated that twining, increase calving difficulty score and mortality level by $7 \%$ compared to cow with singleton birth (Shahid et al., 2015; Atashi et al., 2012). The reason for the observed higher levels of mortality and risk of culling in cows that calves twins probably relates to increase the incidence of some disorders such as dystocia, retain placenta, metritis, displaced abomasum and ketosis (Bell and Roberts, 2007; Fricke, 2001).

\subsection{Calving Season}

The present results indicate that the risk of cows leaving the herd for calving season is much greater in hot season (spring and summer) for calved cows compared to fall and winter $(\mathrm{P}<.001)$. The odds ratio of culling for calving season recorded 1, 1.59, 1.46, and 1.06 for spring, summer, fall and winter, respectively (Table 2). Our observation is consistent with that of Bahrampour et al. (2016) where the hazard ratio of cow culled for calving season decreased in the cool season (fall and winter). One of the important factors affecting the rate of culling in new born calves is the season of calving (Hadley et al., 2006). Therefore, Dechow and Goodling (2008) and Alvasen et al. (2012) reported that seasonal adverse effect on cow survival more observed in spring and summer. In addition to, Pinedo and de Vries (2010) and Miller et al. (2008) indicated that calving in hot season (spring and summer) increased the risk of cows leaving the herd compared to calving in cool season (fall and winter). One of the reasons for increasing the risk of cows leaving the herd in hot season (spring and summer) may be increase the incidence of some disorders such as claw lesions (Madadzadeh et al., 2013). On the other hand, increasing the risk of cows leaving the herd in 
hot season (spring and summer) may also be related to the influence of seasonal characteristic differences on cow health, milk production level, feed availability, milk price, conception rate and profitability (Delorenzo et al., 1992; Hadley et al., 2006).

\subsection{Age at First Calving}

The risk of cows leaving the herd for age at first calving are reported in Table 2. According to the result of current study, age at first calving has been shown to have significant correlations with the risk of cows leaving the herd. The risk of cows leaving the herd increased with the increasing in age at first calving $(\mathrm{P}<.001)$. The odds ratio of culling for age at first calving recorded 1, 1.56, 1.60, and 1.94 for $\leq 728,729-762,763-815$ and $\geq 816$, respectively (Table 2). Vukasinovic et al. (2001) found that the risk of cows leaving the herd for age at first calving increased slightly when the first calving occurred very soon or very late. Similarly, Ducrocq (2005) and M'hamdi et al. (2010) reported an increase in the risk of cows leaving the herd with increasing the age at first calving. As the age increased at first calving, the odd ratio of cow culled for age at first calving increased for for age at first calving (Zavadilova and Stipkova, 2013; Bahrampour et al., 2016). Perusal of the literature indicates that in Holstein cow a calving at about 24 months of age needs to be achieved to have best economic impacts (Heinrichs, 1993). One reason for decreasing the risk of cows leaving the herd for calving at about 24 months of age could be that, better productive and reproductive performance at this age.

\section{Conclusions}

This research provides evidence that increased the risk of cows leaving the herd could be partly mediated by an increase in parity, calving difficulty score, gave birth to twins, hot seasons (spring and summer) and had longer days to first calving. These findings indicate that there is a direct relationship between the management of cow-related characteristics and the culling and help farmers reduce their involuntary culling rates in dairy herds by improving the management of dairy cows in Torbat-e Jam.

\section{Acknowledgement}

The author wishes to thank the Torbat-e jam Faculty of Agriculture and Animal Science for financial support of this research.

\section{References}

Alvasen, K., Jansson Mörk, M., Hallén Sandgren, C., Thomsen, P. T., \& Emanuelson, U. (2012). Herd-level risk factors associated with cow mortality in Swedish dairy herds. Journal of Dairy Science, 95, 4352-4362. https://doi.org/10.3168/jds.2011-5085

Ansari-Lari, M., Mohebbi-Fani, M., \& Rowshan-Ghasrodashti, A. (2012). Causes of culling in dairy cows and its relation to age at culling and interval from calving in Shiraz. Southern Iranian Journal of Veterinary Research Forum, 3, 233-237.

Atashi, H., Abdolmohammadi, A., Dadpasand, M., \& Asaadi, A. (2012). Prevalence, Risk Factors and Consequent Effect of Dystocia in Holstein Dairy Cows in Iran. Asian-Australian 
Journal of Animal Science, 4, 447-451. https://doi.org/10.5713/ajas.2011.11303

Bahrampour, J., Danesh Mesgaran, M., Arabpour, A. R., Vakili, A. R., \& Kezri, A. (2016). Risk factors affecting the culling of Iranian Holstein dairy cows. Journal of Livestock Science and Technology, 4(2), 15-23. https://doi.org/10.22103/jlst.2016.1510

Barrier, A. C., \& Haskell, M. J. (2011). Calving difficulty in dairy cows has a longer effect on saleable milk yield than on estimated milk production. Journal of Dairy Science, 94, 1804-1812. https://doi.org/10.3168/jds.2010-3641

Bell, M. J., \& Roberts, D. J. (2007). Effect of twinning on the feed intake, performance and health of dairy cows. Livestock Science, 107, 274-281.

https://doi.org/10.1016/j.livsci.2006.11.014

Bicalho, R. C., Galvao, K. N., Cheong, S. H., Gilbert, R. O., Warnick, L. D., \& Guard, C. L. (2007). Effect of stillbirth on dam's survival and reproduction performance in Holstein dairy cows. Journal of Dairy Science, 90, 2797-2803. https://doi.org/10.3168/jds.2006-504

Booth, C. J., Warnick, L. D., Grohn, Y. T., Maizon, D. O., Guard, C. L., \& Janssen, D. (2004). Effect of Lameness on Culling in Dairy Cows. Journal of Dairy Science, 87, 4115-4122. https://doi.org/10.3168/jds.S0022-0302 (04)73554-7

Communication from the Commission to the European Parliament, the Council, the European Economic and Social Committee and the Committee of the Regions of 19 September 2007 on a new Animal Health Strategy for the European Union (2007-2013) where «Prevention is better than cure» [COM (2007) 539 final].

Dechow, C. D., \& Goodling, R. C. (2008). Mortality, live culling by sixty days in milk, and production profiles in high- and low-survival Pennsylvania herds. Journal of Dairy Science, 91, 4630-4639. https://doi.org/10.3168/jds.2008-1337

Delorenzo, M., Spreen, T., Bryan, G., \& Beede, D. (1992). Optimizing model: Insemination, replacement, seasonal production, and cash flow. Journal of Dairy Science, 75, 885-895. https://doi.org/10.3168/jds.S0022-0302 (92)77829-1

Dematawewa, C. M., \& Berger, P. J. (1998). Genetic and phenotypic parameters for 305-day yield, fertility, and survival in Holsteins. Journal of Dairy Science, 81, 2700-2709. https://doi.org/10.3168/jds.S0022-0302 (98)75827-8

De Vries, A., Olson, J. D., \& Pinedo, P. J. (2010). Reproductive risk factors for culling and productive life in large dairy herds in the eastern United States between 2001 and 2006. Journal of Dairy Science, 93, 613-623. http://dx.doi.org/10.3168/jds.2009-2573

Didarkhah, M., Danesh Mesgaran, M., Ibrahimi Khoram Abadi, E., Jamili, F., \& Hosseini, S. M. (2013). Characterization and Pattern of Culling in Holstein Dairy Cows in Torbat-E-Jam Area, Northeast of Iran. Journal of Agricultural Studies, 1(2), 151-159. http://dx.doi.org/10.5296/jas.v1i2.3957

Ducrocq, V. (2005). An improved model for the French genetic evaluation of dairy bulls on 
length of productive life of their daughters. Journal of Animal Science, 80, 249-256. https://doi.org/10.1079/ASC41720249

Eaglen, S. A. E., Coffey, M. P., Woolliams, J. A., Mrode, R., \& Wall, E. (2011). Phenotypic effects of calving ease on the subsequent fertility and milk production of dam and calf in UK Holstein-Friesian heifers. Journal of Dairy Science, 94, 5413-5423.

https://doi.org/10.3168/jds.2010-4040

Fetrow, J., Nordlund, K. V., \& Norman, H. D. (2006). Culling: Nomenclature, definitions, and recommendations. Journal of Dairy Science, 89, 1896-1905.

https://doi.org/10.3168/jds.S0022-0302 (06)72257-3

Fricke, P. M. (2001). Review: Twinning in dairy cattle. Professional Animal Science, 17, 61-67. https://doi.org/10.15232/S1080-7446(15)31599-0

Hadley, G. L., Wolf, C. A., \& Harsh, S. B. (2006). Dairy cattle culling patterns, explanations, and implications. Journal of Dairy Science, 89, 2286-2296.

https://doi.org/10.3168/jds.S0022-0302 (06)72300-1

Heinrichs, A. J. (1993). Raising dairy replacements to meet the needs of the 21st century. Journal of Dairy Science, 76, 3179-3187.

https://doi.org/ 10.3168/jds.S0022-0302 (93)77656-0

Madadzadeh, T. Nouri, M., \& Nowrouzian, I. (2013). Breed and season effects on the claw lesions of dairy cows in Ardebil, Iran. Researsh Journal of Animal Science, 7, 18-22. https://doi.org/10.3923/rjnasci.2013.18.22

McConnel, C. S., Lombard, J. E., Wagner, B. A., \& Garry, F. B. (2008). Evaluation of factors associated with increased dairy cow mortality on United States dairy operations. Journal of Dairy Science, 91, 1423-1432. https://doi.org/ 10.3168/jds.2007-0440

M'hamdi, N., Aloulou, R., Brar S. K., Bouallegue, M., \& Ben, Hamouda, M. (2010). Study on functional longevity of Tu-nisian Holstein dairy cattle using a Weibull proportional hazards model. Livestock Science, 132, 173-176. https://doi.org/ 10.1016/j.livsci.2010.05.011

Miller, R. H., Kuhn, M. T., Norman, H. D., \& Wright, J. R. (2008). Death losses for lactating dairy cows in herds enrolled in dairy herd improvement test plans. Journal of Dairy Science, 91, 3710-3715. https://doi.org/10.3168/jds.2007-0943

Mohammadi, G. R., \& Sedighi, A. (2009). Reasons for culling of Holstein dairy cows in Neishaboor area in northeastern Iran. Iranian Journal of Veterinary Research. 10, 278 -282.

Pinedo, P. J., de Vries A., \& Webb, D. W. (2010). Dynamics of culling risk with disposal codes reported by Dairy Herd Improvement dairy herds. Journal of Dairy Science, 93, 2250-2261. https://doi.org/10.3168/jds.2009-2572

Raboisson, D., Cahuzac, E., Sans, P., \& Allaire, G. (2011). Herd level and contextual factors influencing dairy cow mortality in France in 2005 and 2006. Journal of Dairy Science, 94, 1790-1803. https://doi.org/10.3168/jds.2009-2572 


\section{Macrothink}

Journal of Agricultural Studies

ISSN 2166-0379 2018, Vol. 6, No. 1

SAS. (2008). SAS User's Guide: Statistics. Version 9.2. SAS Institute Inc. Cary, North Carolina.

Shahid, M. Q., Reneau, J. K., Chester-Jones, H., Chebel, R. C., \& Endres M. I. (2015). Cow and herd level risk factors for on-farm mortality in Midwest US dairy herds. Journal of Dairy Science, 98, 4401- 4413. https://doi.org/10.3168/jds.2014-8513

Thomsen, P. T., \& Houe, H. (2006). Dairy cow mortality: A review. Veterinary Quarterly, 28, 122-129. https://doi.org/ 10.1080/01652176.2006.9695218

Vukasinovic, N., Moll, J., \& Casanova, L. (2001). Implementation of a routine genetic evaluation for longevity based on survival analysis techniques in dairy cattle populations in Switzerland. Journal of Dairy Science, 84, 2073-2080.

https://doi.org/10.3168/jds.S0022-0302 (01)74652-8

Zavadilová, L., \& Stipkova M. (2013). Effect of age at first calving on longevity and fertility Holstein cattle. Czech Animal Science, 58, 47-57.

\section{Copyright Disclaimer}

Copyright for this article is retained by the author(s), with first publication rights granted to the journal.

This is an open-access article distributed under the terms and conditions of the Creative Commons Attribution license (http://creativecommons.org/licenses/by/4.0/). 